\title{
Assessment of Quality of Asphalt Concrete used in Road Construction in South West Nigeria
}

\author{
M. T. Akinleye, M. A. Tijani* \\ Department of Civil Engineering, Faculty of Engineering, Adeleke University Ede, Nigeria.
}

\begin{abstract}
Assessment of asphalt concrete used for pavement construction in southwest Nigeria was carried out to determine the causes of untimely failure of newly constructed/rehabilitated asphalt roads. Samples of asphalt concrete and bitumen were collected from three asphalt plants selected for the study. Samples from each plant were subjected to bitumen extraction and sieve analysis, hot mix Marshall Stability and flow tests, penetration and viscosity tests. Results obtained were compared to the 2007 Federal Ministry of Works and Housing Standard Specifications for Roads and Bridges. The results revealed that none of the samples met all the criteria stated in the specifications, suggesting that the nature of asphalt concrete is a possible cause of premature failure of road pavements in southwest Nigeria. It is recommended that further research be conducted on other constituents of asphalt concrete as well as other structures of the flexible pavement.
\end{abstract}

KEYWORDS: Asphalt concrete, aggregate, bitumen, pavement, road, sieve analysis.

[Received May 24 2017; Revised September 28 2017; Accepted October 2 2017]

\section{INTRODUCTION}

High-quality road networks are very important to the socio-economic development of any nation, especially the developing country like Nigeria. According to Akiije and Oyekan (2012), asphalt can be said to be a relatively thin high quality bituminous surface material on top of series of granular layers of a flexible pavement. Bitumen is used in producing asphalt because of their excellent cementing power, waterproofing properties and low cost (Adedimila, 2000). The surface layer of the pavement structure is the most important layer as it is expected to provide the ultimate function of an economic, safe and comfortable riding surface to users, protecting the sub-structure layers (base, sub-base and subgrade) from infiltration of water and other foreign materials, and distribute stress from axle loads satisfactorily to layers beneath without compromising durability.

The premature failure of road pavement shortly after construction or rehabilitation without meeting its designed life span has become a major challenge to highway engineers, contractors and the government in Nigeria. A study carried out by Federal Road Safety Corps of Nigeria (FRSC, 2011) discovered that out of every 10,000 population, 162 deaths occur as a result of road crashes and Nigeria is currently ranked 191 of 192 countries with unsafe roads. According to CBN (2003), Nigeria road network is about $194,000 \mathrm{~km}$. The Local Governments are in charge of $67 \%$, State Government $16 \%$ and Federal Government $17 \%$. The World Fact Book of Central Intelligence Agency (2004) has it that out $193200 \mathrm{~km}$ of total road network in Nigeria, 28,980 km are paved while $164,220 \mathrm{~km}$ are not. Governments at all levels in Nigeria are presently embarking on road construction to provide networks of good roads to facilitate the transport of goods and services. However, many highways and roads are considered unsafe for vehicular movement because of pavement failures arising from the development of potholes and other road stress characteristics in the early life of the road between two to three years (Ogunribido et al, 2015)

Road failure is when the infrastructural facility must have collapsed entirely. Road failure has caused set back to Nigerian economy by claiming many lives and property worth millions of naira trough road crashes. The causes of roads failure in Nigeria have as found identified by many researchers include poor construction materials, poor design and specification, road usage, poor drainage, geological and geotechnical factors (Aghamelu and Okogbue, 2011; Ofonime and Aniekan, 2005; Jegede, 2000; Adeyemi and Oyeyemi, 2000; Gidigasu, 1980).

This study aims to investigate the properties of asphalt concrete used for pavement construction in Nigeria in order to determine if they are among the causes of untimely road failure. The study will collect asphalt samples from three different asphalt plants in southwest for bitumen extraction and sieve analysis, Marshall Stability and flow tests, penetration and viscosity tests. Result of the tests will be compared to 2007 Federal Ministry of Works and Housing Standard Specifications for Roads and Bridges to make appropriate recommendations.

\section{METHODOLOGY}

Samples of asphalt concrete and bitumen were collected from three prominent asphalt plants that produce asphalt for pavement construction within the southwest Nigeria. The plants are Lagos State Public Works Corporation (Sample A), Shuingi Asphalt Plant Company (Sample B) and Borini Prono \& Co. (Nig.) Ltd. (Sample C). ASTM D2172 - 05 test method was used for the quantitative determination of bitumen in asphalt concrete samples. Aggregate obtained by these test methods was used for sieve analysis adopting 
ASTM C 136 test methods. The procedures in ASTM D692705 test method was used for Marshall Stability and flow of asphalt concrete. Samples of grade 60/70 asphalt cement (bitumen) used in the production of the asphalt concrete were subjected to penetration and viscosity tests. AASHTO T 4906 test methods were used for bitumen penetration while AASHTO T 72-97 was adopted for Saybolt viscosity test. Results obtained were compared to the 2007 Federal Ministry of Works and Housing Standard Specifications for Roads and Bridges to determine if asphalt produced in southwest Nigeria contributes to its untimely road failure.

\section{RESULTS AND DISCUSSION}

\section{A. Asphalt Concrete Properties}

Table 1 shows the properties of asphalt concrete of sample A. Table 2 shows that of sample B while Table 3 shows the properties of asphalt concrete of sample $\mathrm{C}$. The three tables were obtained from the results of bitumen extraction, Marshall Stability and flow tests. Comparisons of the results of properties of asphalt concrete with FMW (2007) standard specification are also displayed in Tables 1-3. Figures 1, 2 and 3 show the result of the sieve analysis of aggregates extracted from asphalt concrete made with Sample $\mathrm{A}, \mathrm{B}$ and $\mathrm{C}$ respectively.

Table 1: Properties of asphalt concrete of Sample A.

\begin{tabular}{llll}
\hline Properties & $\begin{array}{l}\text { Test } \\
\text { results }\end{array}$ & $\begin{array}{l}\text { FMW } \\
\text { Specification }\end{array}$ & Remarks \\
\hline Bitumen Content & $5.4 \%$ & $5.0-8.0 \%$ & Passed \\
Stability & $2,846.72 \mathrm{~N}$ & $\geq 3,500.00 \mathrm{~N}$ & Failed \\
Flow & $1.70 \mathrm{~mm}$ & $2 \mathrm{~mm}-4 \mathrm{~mm}$ & Failed \\
Voids in Total & $15.45 \%$ & $3 \%-5 \%$ & Failed \\
Mix & $41.81 \%$ & $75 \%-82 \%$ & Failed \\
Voids Filled & & & \\
\hline
\end{tabular}

Table 2: Properties of asphalt concrete of Sample B.

\begin{tabular}{llll}
\hline Properties & Test results & FMW Limits & Remarks \\
\hline Bitumen Content & $5.8 \%$ & $5.0-8.0 \%$ & Passed \\
Stability & $1,561.25 \mathrm{~N}$ & $\geq 3,500.00 \mathrm{~N}$ & Failed \\
Flow & $1.05 \mathrm{~mm}$ & $2 \mathrm{~mm}-4 \mathrm{~mm}$ & Failed \\
Voids in Total Mix & $11.21 \%$ & $3 \%-5 \%$ & Failed \\
Voids Filled & $52.58 \%$ & $75 \%-82 \%$ & Failed \\
\hline
\end{tabular}

Table 3: Properties of asphalt concrete of Sample C.

\begin{tabular}{llll}
\hline Properties & Test results & FMW Limits & Remarks \\
\hline Bitumen Content & $6.2 \%$ & $5.0-8.0 \%$ & Passed \\
Stability & $4,932.83 \mathrm{~N}$ & $\geq 3,500.00 \mathrm{~N}$ & Passed \\
Flow & $2.80 \mathrm{~mm}$ & $2 \mathrm{~mm}-4 \mathrm{~mm}$ & Passed \\
Voids in Total Mix & $6.66 \%$ & $3 \%-5 \%$ & Failed \\
Voids Filled & $67.62 \%$ & $75 \%-82 \%$ & Failed \\
\hline
\end{tabular}

The gradation chart obtained as in Figures 1-3 showed that none of the samples fell completely within the lower and upper limits specified by FMW (2007) standard specifications. The non-conformity of the extracted aggregate with the specification could hinder some other properties of asphalt concrete. It could be observed from Table 1 that the bitumen content of sample A $(5.4 \%)$ passed the requirement of FMW (2007) (5\% - 8\%). Results of stability of sample A $(2,846.72 \mathrm{~N})$ was found to be less than $3,500.00 \mathrm{~N}$ specified in the standard; hence Sample A fell short in this regards or failed. Flow, voids in total mix, and voids filled by bitumen were also noticed to fail the requirement of FMW (2007).

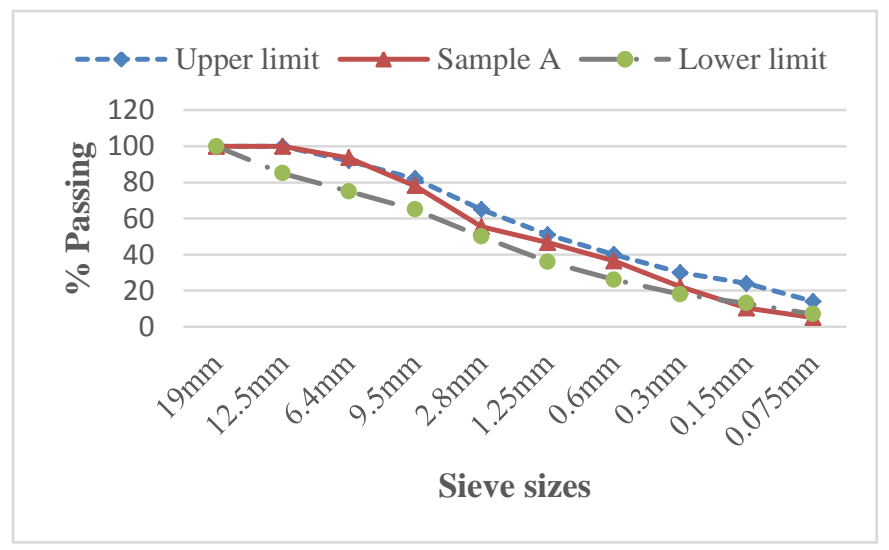

Figure 1: Sieve analysis of aggregates extracted from Sample A.

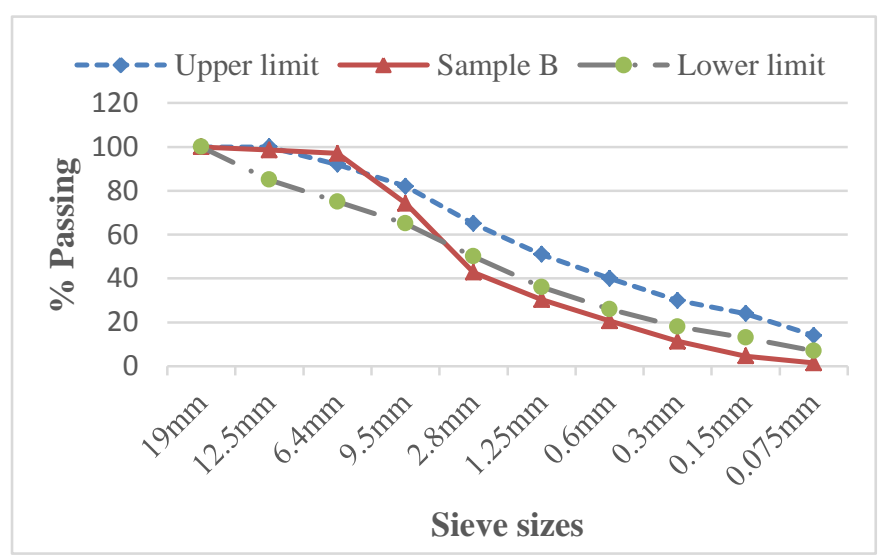

Figure 2: Sieve analysis of aggregates extracted from Sample B.

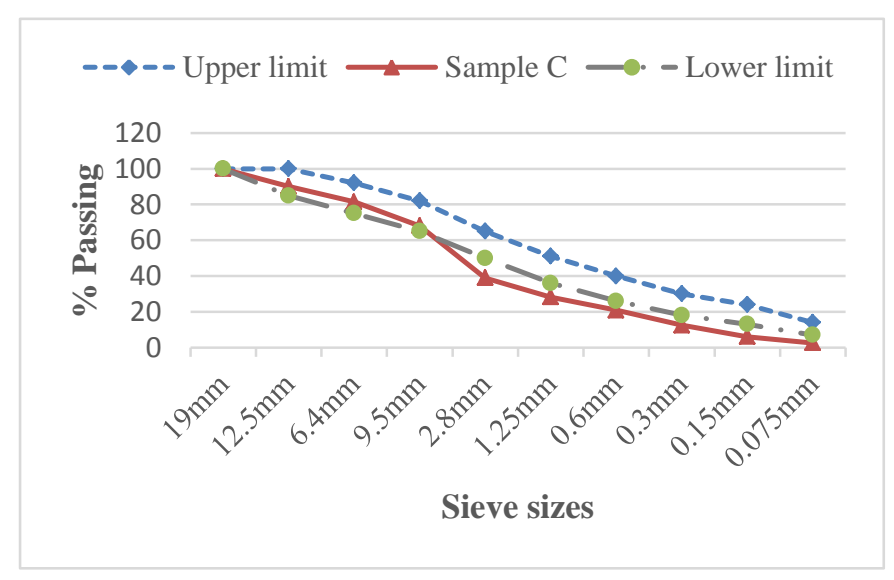

Figure 3: Sieve analysis of aggregates extracted from Sample C. 
The bitumen content of sample B passed the requirement of FMW (2007) as shown in Table 2. Sample B stability fell below the standard requirement. Its flow was found to be 1.05 $\mathrm{mm}$ which is less the minimum $2 \mathrm{~mm}$ specified in the FMW (2007) standard. Voids in total mix was $11.21 \%$, this result fell out of $3 \%-5 \%$ range in the specification. The voids filled by bitumen in Sample B failed when compared to the requirement of FMW (2007) as well. Table 3 recorded a good result for bitumen content in sample $\mathrm{C}(6.2 \%)$. This result passed the requirement (5\% - 8\%) of FMW (2007). Sample C has stability of $4,932.83 \mathrm{~N}$ which is above the minimum of $3,500.00 \mathrm{~N}$ specified. This satisfactory stability could be linked to the presence of more coarse aggregate materials in sample $\mathrm{C}$ when compared with samples $\mathrm{A}$ and $\mathrm{B}$ as shown in Figures $1-3$. The flow of an asphalt concrete which is a function of the adequacy of bitumen content in mix as well as adequate gradation of the constituent aggregates was passed by this sample as well. Neither voids in total mix nor voids filled with bitumen passed the requirement of FMW (2007) specification by this sample.

According to Roberts et al (1996) excess voids in the mix often lead to infiltration of asphalt concrete by foreign bodies and may results to failure of the asphalt concrete. A good mix design of asphalt concrete must consist of adequate amount of all materials in the component. The inadequacy of a particular material, will affects the overall performance of the asphalt concrete. For instance, adequate amount of bitumen with poor gradation of mineral matter will result in low stability and flow as well as excess voids in the concrete. This is due to the fact that the coarse aggregates give the strength required to achieve adequate stability, the fine aggregates serve as an interlocking agent, filling the pores within the coarse aggregate, thus reducing the amount of voids in the concrete, thereby enhancing adequate flow.

Furthermore, excess bitumen in a mix where other components are adequate will also result to poor properties of the asphalt concrete, as the excess bitumen will lead to excess flow of the mix. This is the cause of bleeding and slipping of asphalt concrete under traffic loading (Salter, 1994).

\section{B. Bitumen Properties}

Table 4 shows the summary of the penetration test results on bitumen samples. The table shows the validation of the test results when compared with the FMW (2007) standard specifications. However, it could be observed all the samples had penetration above the grade of $60-70$ penetration value stated in the specification for tropical region like the study area. This is an indication that the bitumen is softer, thus confirming the presence of dilutants which may vaporize during the production of asphalt concrete thus reducing the amount of bitumen in the mix and may subsequently leads to premature failure of the concrete.

Figure 4 shows the result of viscosity tests in comparison with the upper and lower limits specification of FMW (2007). It could obviously be seen from the Figure 4 that none of the three samples conform to grade AC 20 recommended for the production of hot mixed-hot laid asphalt for highways in tropical region like southwest Nigeria.
According to Gupta and Gupta (2007), bitumen at viscosity grade of AC20 will provide a uniform film for binding action in tropical region, while bitumen with higher viscosity will resist compacting effort. Bitumen with lower viscosity will only lubricate the aggregate particles.

Table 4: Penetration Tests on Bitumen Samples.

\begin{tabular}{|c|c|c|c|c|c|c|}
\hline \multirow{2}{*}{$\begin{array}{l}\text { Asphalt } \\
\text { Plant } \\
\text { Samples }\end{array}$} & \multirow{2}{*}{$\begin{array}{l}\text { No of } \\
\text { Test } \\
\text { Times }\end{array}$} & \multicolumn{3}{|c|}{ Penetration Values (Pen) } & \multirow{2}{*}{$\begin{array}{l}\text { FMW } \\
\text { Specificat } \\
\text { ion (Pen) }\end{array}$} & \multirow[t]{2}{*}{ Remarks } \\
\hline & & Initial & Final & Mean & & \\
\hline \multirow{3}{*}{ A } & Test 1 & 0 & 80 & \multirow{3}{*}{74} & \multirow{3}{*}{$60-70$} & \multirow{3}{*}{ Failed } \\
\hline & Test 2 & 0 & 70 & & & \\
\hline & Test 3 & 0 & 72 & & & \\
\hline \multirow{3}{*}{ B } & Test 1 & 0 & 110 & \multirow{3}{*}{114} & \multirow{3}{*}{$60-70$} & \multirow{3}{*}{ Failed } \\
\hline & Test 2 & 0 & 130 & & & \\
\hline & Test 3 & 0 & 101 & & & \\
\hline \multirow{3}{*}{$\mathrm{C}$} & Test 1 & 0 & 100 & \multirow{3}{*}{85} & \multirow{3}{*}{$60-70$} & \multirow{3}{*}{ Failed } \\
\hline & Test 2 & 0 & 72 & & & \\
\hline & Test 3 & 0 & 84 & & & \\
\hline
\end{tabular}

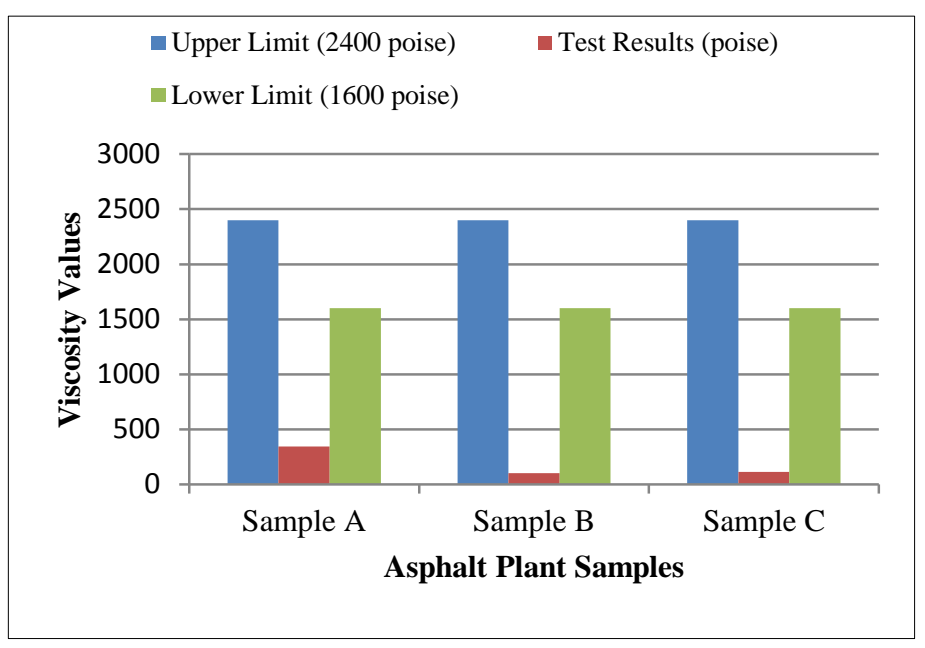

Figure 4: Saybolt viscosity test results for bitumen samples.

\section{CONCLUSION}

A practical approach has been presented for the assessment of asphalt concrete used for pavement construction in southwest Nigeria in order to determine if the quality of the concrete is among the causes of untimely failure of newly constructed/rehabilitated asphalt roads. The comprehensive assessment used in this study revealed that none of three samples of the asphalt concrete examined was able to fully meet the stated benchmarks in the FMW (2007) specifications. It is concluded that the use of poorly graded mineral aggregates, poor and inadequate bitumen content resulted in the mix having poor stability, inadequate flow and excess voids. The unsatisfactory results from bitumen properties as shown in this study may significantly affect the performance of asphalt concrete leading to untimely failure of asphalt roads in southwest Nigeria. 


\section{REFERENCES}

AASHTO T 49-06 (2006). Penetration of bituminous materials, in standard specifications for transportation materials and methods of sampling and testing. (26th Edition). American Association of State Highway and Transportation Officials, Washington, D.C

AASHTO T 72-97 (2001). Saybolt Viscosity. standard specifications for transportation materials and methods of sampling and testing. (26th edition). American Association of State Highway and Transportation Officials, Washington, D.C

Adedimila, A. S. (2000). Bitumen: Nigeria's other black gold? Inaugural Lecture Series, University of Lagos.

Adeyemi, G. O. and Oyeyemi, F. (2000). Geotechnical basis for failure of sections of the Lagos-Ibadan expressway, Southwestern Nigeria. Bulletin of Engineering Geology and Environment, 59(1): 39-45.

Aghamelu, O. P. and Okogbue, C. O. (2011). Geotechnical assessment of road failure in the Abakaliki Area, Southeastern Nigeria. Intern'l Journal of Civil and Environmental engineering 11(2): 12 - 24.

Akiije, I. and Oyekan, G. L (2012). Stabilization assessment of aggregates in asphalt concrete mixtures. International Journal of Scientific \& Engineering Research. 3(4): 695-699.

ASTM (American Society for Testing and Materials). (2001). Standard test method for sieve analysis of fine and coarse aggregates. C136. West Conshohocken, PA, USA.

ASTM (American Society for Testing and Materials). (2005). Standard test method for marshall stability and flow of asphalt mixtures. D6927. West Conshohocken, PA, USA.

ASTM D2172-05, Standard test methods for quantitative extraction of asphalt binder from asphalt Mixtures, ASTM International, West Conshohocken, PA, 2005.
Central Bank of Nigeria (CBN) (2003). Highway maintenance in Nigeria; lessons from other countries. Research Department Occasional Paper No. 27.

Federal Road Safety Corps (2011). United Nations decade of action on road safety. Benin City Nigeria.

FMW. (2007). Pavement and materials design in highway manual part 1: Design. Volume 3, Federal Ministry of Works, Abuja, Nigeria

Gidigasu, M. D. (1980). Geotechnical evaluation of residual gravels in pavement construction. Engineering Geology, 15(3/4): 173-194.

Gupta, B. L. and Gupta, A. (2007). Roads, railways bridges tunnels \& harbour dock engineering. Standard Publishers Distributors, 1705-B, Nai Sarak, Delhi.

Jegede, G. (2000). Effect of soil properties on pavement failure along the F209 highway at Ado-Ekiti, Southwestern Nigeria. Construction and Building Materials, 14: 311- 315.

Ofonime, A. and Aniekan, E. (2005). Relationship between road pavement failures, Engineering indices and underlying Geology in a tropical environment. Global Journal of Geological Sciences, 4(2): 99 - 108.

Ogunribido T. H. T, Mohammed M. Z., Adesuyi A. R. (2015) Effect of engineering properties of soil on pavement failures in Ogbagi-Akoko area, Southwestern, Nigeria. Journal of Environment and Earth Science. 5(4): 39-42.

Roberts, F. L., Kandhal, P. S., Brown, E. R., Lee, D. Y. and Kennedy, T. W. (1996). Hot mix asphalt materials, mixture design and construction. National Asphalt Pavement Association Education Foundation, Lanham, MD.

Salter, R. J. (1994). Highway design and construction (2nd ed.), Macmillan Press Ltd, UK.

World Factbook (2004) available on the Central Intelligence Agency Website https://www.cia.gov 